\section{An Amazing Spring}

\section{Dr. Stuart Houston, Yorkton}

7 THIS has been an amazing season. 1 The snow was gone two weeks earlier than average, and the trees were in leaf a full three weeks early. The birds, however, are not so far ahead of schedule.

Our first Sunday morning bird hike at Rousay Lake on April 27 disclosed 32 species-an April record.

Our second Y.N.H.S. hike on May 11 found a total of 50 species at Leech Lake. A young Great Horned Owl, just out of the nest was banded. Later that day, on Lower Rousay Lake, I found a Canada Goose nest with 5 eggs.

I spent May 24th and 25th at my wife's home on a farm south of Dilke, Sask. (56 miles northwest of Regina) and on May 24 we visited nearby Last Mountain Lake. 65 different species of birds were observed during the two days.

At Dilke, we watched 12 sharptailed grouse "dancing" on a stubb!e knoll. Previously grassy, this land has been under cultivation for two years and the grouse have continued to use it as a dancing ground in spite of this. They have tramped the stubble flat on the top of the knoll.

The first duck broods of 8,9 and 7 Mallards, and 10, 7, 5 and 4 Pintails were noted on the 24th and 25th.

Henry McArton and J. B. Belcher report a further increase in the numbers of Hungarian Partridges and Sharp-tailed Grouse at Dilke. and say both species are as plentiful as they ever have been.

\section{Unprecedented Numbers}

\section{Arthur Ward, Swift Current.}

NEVER, during the term of our residence here, has there been such an array of different bird species on the miniature lakes which dot the open prairie. Grebes, coots, bitterns and many others, frequenters of larger waters, are seen nesting a few yards from the roadside ditches.

I photographed a Horned Grebe's nest, containing four eggs. Just then I was surprised to see a beaver swimming along the water's edge, though many miles from any natural habitat. I noticed some poplars growing well back from the road which might proviae the beaver with its requirements.

There has also been an unprecedented number of thrushes in migration. The Olive-backed Thrush had come and gone before the Greychecked put in an appearance. Although some species have not yet arrived, others are hatching out their young. The early incubation may induce second batches where not often customary.

\section{Blackie, the Crow}

Henry Savard - Carvel, Alta.

I HAVE caught and tamed many birds, mostly juncos, snowbirds, crows and magpies, and I have found the crow to be the most interesting and easily tamed.

Blackie was my last crow. He was very tame and mischievous, and enjoyed playing tricks. Whenever I was building something he would be waiting to hide the nails, ruler or anything he could find.

One day when I was building, I set a handful of nails down within my reach and while I was measuring some boards, I turned to find that the nails were gone. Then I saw Blackie hurriedly trying to hide a last mouthful in some grass. I recovered my nails and had to smile as I heard him squawk disappointedly. He also used to annoy the dogs by pulling and pecking at their tails.

I would like to know where I could acquire bands for crows, magpies and also song birds. I am interested in banding.

(Write Mr. Fred Bard, Director, Provincial Museum, Regina.)

\section{Starlings at Lintlaw}

$$
\text { C. St. A. Nixon }
$$

I saw five European Starling here on March 31 , my first in 42 years. They were foraging on the ground in a neighbour's yard. I think I saw five or six about the same time last year but they were in flight and I could not be sure. On this occasion there was no mistaking the characteristic starling strut. They disappeared, as they did last year, after only one appearance. 